\title{
PENGARUH PROFESIONALISME GURU DAN MOTIVASI KERJA TERHADAP KINERJA GURU EKONOMI SMA SE-KOTA MALANG
}

\author{
Tiara Anggia Dewi \\ Program Studi Pendidikan Ekonomi Universitas Muhammadiyah Metro \\ E-mail: tiara.anggia09@gmail.com
}

\begin{abstract}
Abstrak
Penelitian ini bertujuan untuk menjelaskan: (1) pengaruh profesionalisme guru terhadap kinerja guru ekonomi, (2) pengaruh motivasi kerja terhadap kinerja guru ekonomi, (3) pengaruh profesionalisme guru dan motivasi kerja terhadap kinerja guru ekonomi. Penelitian ini dirancang sebagai penelitian eksplanasi. Subjek penelitian ini adalah seluruh guru ekonomi di SMA Se-kota Malang yang berjumlah 82 orang. Data dikumpulkan dengan instrumen berupa kuesioner. Data dianalisis dengan analisis statistik inferensial dengan analisis regresi linear berganda. Berdasarkan hasil analisis data menunjukkan secara parsial profesionalisme guru berpengaruh positif dan signifikan terhadap kinerja guru ekonomi dengan nilai sig. $\mathrm{t}$ sebesar $(0,000)<\alpha(0,05)$ dan $t_{\text {hitung }}(4,361)>t_{\text {tabel }}(1,666)$. Analisis pengaruh motivasi kerja terhadap kinerja guru ekonomi secara parsial berpengaruh positif dan signifikan dengan nilai sig. $\mathrm{t}$ sebesar $(0,000)<\alpha(0,05)$ dan $t_{\text {hitung }}(3,650)>\mathrm{t}$ tabel $(1,666)$. Secara simultan profesionalisme guru dan motivasi kerja berpengaruh positif dan signifikan terhadap kinerja guru ekonomi dengan nilai sig. F sebesar $(0,000)<\alpha(0,05)$.

Selain itu, dari hasil analisis regresi besar R Square adalah 0,530.
\end{abstract}

Kata Kunci: Profesionalisme, Motivasi, Kinerja

\section{PENDAHULUAN}

Peningkatan kualitas pendidikan merupakan agenda besar pendidikan di Indonesia. Dalam rangka mewujudkan pendidikan yang bermutu tentu tidak terlepas dari peranan berbagai pihak, salah satunya adalah peran tenaga kependidikan. Hamalik (2003 : 9) tenaga kependidikan merupakan suatu komponen yang penting dalam penyelenggaraan pendidikan, yang bertugas menyelenggarakan kegiatan mengajar, melatih, meneliti, mengembangkan, mengelola dan memberikan pelayanan teknis dalam bidang kependidikan.
Dalam upaya peningkatan mutu pendidikan, aspek utama yang ditentukan adalah kualitas guru. Hal ini disebabkan guru merupakan titik sentral dalam pembaharuan dan peningkatan mutu pendidikan, dengan kata lain salah satu persyaratan penting bagi peningkatan mutu pendidikan adalah apabila pelaksanaan proses belajar mengajar dilakukan oleh pendidik-pendidik yang dapat diandalkan keprofesionalannya.

Agus F. Tamyong dalam Usman (2010:15) menyatakan pengertian guru profesional adalah orang yang memiliki kemampuan dan keahlian khusus dalam 
bidang keguruan sehingga ia mampu melakukan tugas dan fungsinya sebagai guru dengan kemampuan maksimal. Kualifikasi pendidikan guru sesuai dengan prasyarat minimal yang ditentukan oleh syarat-syarat seorang guru yang profesional. Undang-Undang Guru dan Dosen No. 14 Tahun 2005 menjelaskan bahwa profesional adalah pekerjaan atau kegiatan yang dilakukan oleh seseorang dan menjadi sumber penghasilan kehidupan yang memerlukan keahlian, kemahiran, atau kecakapan yang memenuhi standar mutu atau norma tertentu serta memerlukan pendidikan profesi.

Selanjutnya dalam melakukan kewenangan profesionalismenya, guru dituntut memiliki seperangkat kemampuan (competency) yang beraneka ragam. Dalam Undang-Undang Guru dan Dosen No. 14 Tahun 2005 dan Peraturan Pemerintah No. 19 Tahun 2005 dinyatakan bahwa kompetensi guru meliputi kompetensi kepribadian, kompetensi pedagogik, kompetensi profesional dan kompetensi sosial. Berlakunya undang-undang dan peraturan tersebut menuntut para guru untuk meningkatkan profesionalismenya melalui pelatihan, penulisan karya ilmiah, dan sebagainya.

Luthans (2008: 158) mengemukakan bahwa "Motivation is a process that starts with a physiological or psychological deficiency or need that activates a behavior or a drive that is aimed at a goal or incentive”. Guru yang memiliki motivasi tinggi akan memandang berbagai kekurangan yang ada di sekolah sebagai tantangan. Ia akan berusaha sedapat mungkin untuk mengatasi kekurangan itu. Dengan adanya perhatian yang baik terhadap guru, akan dapat menimbulkan motivasi para guru untuk berbuat yang terbaik dalam melakukan tugas sehingga menumbuhkan komitmen dalam melakukan pekerjaan yang berkualitas dan bertanggung jawab demi kemajuan organisasi.

Di dalam suatu organisasi, kinerja memiliki pengaruh yang sangat besar bagi tercapainya tujuan organisasi tersebut. Kinerja dapat diartikan sebagai hasil kerja yang dapat dilihat secara kualitas maupun kuantitas ketika seseorang melakukan tugas yang menjadi tanggung jawabnya. Ungkapan kemajuan yang didasari oleh pengetahuan, keterampilan dan sikap serta motivasi untuk menghasilkan sesuatu adalah kinerja (Fattah, 2003:27). Kinerja seorang guru dikatakan baik apabila guru tersebut mampu menguasai dan mengembangkan bahan pelajaran, kreatif dalam penyampaian pembelajaran, mampu menunjukkan komitmen yang tinggi pada tugas mengajar, disiplin dalam pekerjaan, melakukan kerjasama dengan semua warga sekolah, serta memiliki kepribadian yang menjadi panutan bagi siswa. 
Guru ekonomi dituntut untuk mengikuti perubahan-perubahan yang terjadi dalam pembelajaran ekonomi. Oleh karena itu, merupakan suatu keharusan bagi guru untuk selalu meningkatkan profesionalitasnya. Guru ekonomi harus senantiasa memperbaharui materi-materi serta isu-isu ekonomi terkini sehingga proses pembelajaran akan menjadi lebih menarik dan bermakna. Di samping itu, guru ekonomi harus memiliki kepekaan yang tinggi terhadap perubahan-perubahan yang terjadi dalam dunia pendidikan, seperti perubahan kurikulum 2013. Guru harus cepat beradaptasi dengan cara mengikuti penataran, pelatihan dan workshop agar dapat menyampaikan pembelajaran yang sesuai dengan peraturan kurikulum terbaru.

Penelitian dilakukan di seluruh SMA dikota Malang dikarenakan permasalahan yang masih banyak ditemukan terkait dengan kinerja guru di Kota Malang. Hal ini seperti yang diungkap oleh Santoso (2013:1) yang menyatakan bahwa:

Guru bersertifikasi mau menerima uang tunjangan sertifikasi, tetapi enggan meningkatkan kualitas profesionalismenya. Banyak guru yang jam terbangnya sudah kadaluwarsa, namun metode mengajarnya masih konvensional. Pembelajaran masih berpusat pada guru, tidak terjadi interaksi yang multiarah (guru dengan siswa, siswa dengan guru, siswa dengan siswa, siswa dengan lingkungan pembelajaran). Sehingga sama sekali tak mencerminkan pembelajaran yang aktif, kreatif, dan menyenangkan. Sedangkan masalah gairah mengajar terkait erat dengan menurunnya motivasi mengajar yang disebabkan oleh jamak alasan. Mengajar dianggap sebagai tugas rutin dan keseharian, bukan sebagai tugas profesional. Sehingga guru kurang termotivasi untuk melakukan berbagai pembaharuan. Akibatnya kreatifitas dan inovasi guru dalam merekayasa pembelajaran sering mandeg.

Mengingat tugas guru yang sangat penting dalam menghasilkan siswa lulusan yang siap melanjutkan pendidikan ke perguruan tinggi, kinerja guru SMA harus diperhatikan dengan sebaik-baiknya. Dengan demikian, penelitian ini bertujuan untuk mengetahui seberapa besar faktor profesionalisme guru dan motivasi kerja yang mempengaruhi kinerja guru ekonomi di SMA, khususnya di kota Malang

\section{KAJIAN PUSTAKA}

\section{Hakikat Profesionalisme Guru}

Komarudin (2000 : 205) mengemukakan bahwa profesional berasal dari bahasa latin yaitu "profesia", pekerjaan, keahlian, jabatan, jabatan guru besar. Seorang yang melibatkan diri dalam salah satu keahlian yang harus dipelajari dengan khusus. Jarvis dalam Sagala (2006:198) profesional dapat diartikan bahwa seseorang yang melakukan tugas profesi juga sebagai ahli (expert) apabila 
dia secara spesifik memperolehnya dari belajar. Sedangkan Tilaar (2002:86) mengemukakan bahwa:

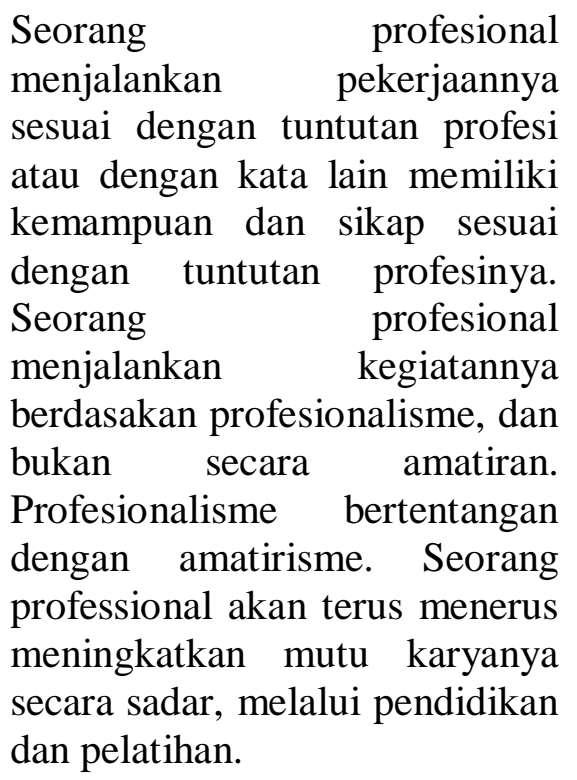

Hakikat guru profesional adalah guru yang mampu memberikan pelayanan yang terbaik bagi para siswanya dengan kemampuan khusus yang dimilikinya, sehingga siswa dapat menerima dan memahami penyampaian materi yang diberikan. Seorang guru tidak hanya dituntut untuk memiliki kemampuan teknis edukatif dalam melaksanakan tugasnya, tetapi juga harus memiliki karakter yang dapat diandalkan sehingga dapat menjadi panutan bagi siswa, keluarga, dan masyarakat. Pembinaan karakter profesional guru mendorong pengembangan potensi guru secara terus menerus dan berkesinambungan sesuai dengan kebutuhan pengajaran masing-masing guru.
Mulyasa (2008:75) kompetensi yang harus dimiliki guru dapat dijabarkan sebagai berikut:

a. Dalam Standar Nasional Pendidikan, penjelasan Pasal 28 ayat (3) butir a dikemukakan bahwa kompetensi pedagogik adalah kemampuan mengelola pembelajaran peserta didik meliputi pemahaman terhadap peserta didik, perancangan dan pelaksanaan pembelajaran, evaluasi hasil belajar, dan pengembangan peserta didik untuk mengaktualisasikan berbagai kompetensi yang dimilikinya.

b. Dalam Standar Nasional Pendidikan, penjelasan Pasal 28 ayat (3) butir b kompetensi kepribadian adalah kemampuan kepribadian yang mantap, stabil, dewasa, arif dan berwibawa, menjadi teladan bagi peserta didik, dan berakhlak mulia.

c. Dalam Standar Nasional Pendidikan, penjelasan Pasal 28 ayat (3) butir c kompetensi profesional adalah kemampuan penguasaan materi pembelajaran secara luas dan mendalam yang memungkinkannya membimbing peserta didik memenuhi standar kompetensi yang ditetapkan.

d. Dalam Standar Nasional Pendidikan, penjelasan Pasal 28 ayat (3) butir d Kemampuan sosial adalah kemampuan pendidik sebagai bagian dari masyarakat untuk berkomunikasi dan 
bergaul secara efektif dengan peserta didik, sesama pendidik, tenaga kependidikan, orang tua/wali peserta didik, dan masyarakat sekitar.

\section{Hakikat Motivasi Kerja}

Perilaku kerja seseorang pada hakikatnya ditentukan oleh keinginannya untuk mencapai tujuan tertentu. Keinginan merupakan istilah lain dari motivasi. Menurut Hasibuan (2003:95), motivasi berasal dari kata dasar motif, yang mempunyai arti suatu perangsang, keinginan dan daya penggerak kemauan bekerja seseorang. Sedangkan menurut Robbins (2007:166), motivasi adalah kesediaan untuk mengeluarkan tingkat upaya yang tinggi untuk tujuan organisasi yang dikondisikan oleh kemampuan upaya itu dalam memenuhi beberapa kebutuhan individual.

Motivasi kerja seorang guru adalah keadaan yang membuat guru mempunyai kemauan atau keinginan untuk mencapai tujuan tertentu melalui pelaksanaan tugastugas keguruan. Motivasi kerja guru akan memberikan kekuatan untuk melaksanakan aktivitas pekerjaan sehingga menyebabkan seorang guru mengetahui adanya tujuan yang relevan antara tujuan organisasi dengan tujuan pribadinya. Dengan demikian, dapat disimpulkan bahwa tujuan dan sasaran-sasaran dalam organisasi sekolah akan tercapai apabila semua komponen organisasi termasuk guru memiliki motivasi yang tinggi secara optimal.

Adapun faktor-faktor yang mempengaruhi motivasi kerja guru menurut Roth et al (2007) yaitu:

a. Motivasi ekstrinsik yang meliputi:

1) Penghargaan atas usaha dan prestasi guru

2) Kepuasan terhadap cara mengajar

3) Pengamatan Kepala Sekolah terhadap pekerjaan guru

b. Motivasi intrinsik yang meliputi:

1) Cara mengajar yang menyenangkan

2) Hubungan dengan orang tua siswa yang harmonis

3) Hubungan dengan siswa yang harmonis

\section{Hakikat Kinerja Guru}

Kinerja merupakan terjemah dari bahasa inggris work performance atau job performance atau performance saja. Dalam kamus besar bahasa indonesia "Kinerja adalah suatu yang dicapai, prestasi yang diperlihatkan dalam kemampuan kerja" (Depdiknas, 2003). Kinerja sangat berkaitan dengan hasil kerja. Hasibuan (2003:94) menyatakan bahwa kinerja atau prestasi kerja adalah suatu hasil kerja yang dicapai seseorang dalam melaksanakan tugas yang dibebankan kepadanya yang didasarkan atas kecakapan, pengalaman, dan kesungguhan serta waktu. 
Mangkuprawira dalam Yamin (2007 : 155) menjelaskan bahwa kinerja merupakan suatu kontruksi multi dimensi yang mencakup banyak faktor yang mempengaruhinya, faktor-faktor tersebut adalah :

a. Faktor Personal/individual, meliputi unsur pengetahuan, keterampilan (skill), kemampuan, kepecayaan diri,motivasi dan komitmen yang dimiliki oleh tiap individu guru.

b. Faktor kepemimpinan, meliputi aspek kualitas manajer dan team leader dalam memberikan dorongan, semangat, arahan, dan dukungan kerja pada guru.

c. Faktor tim, meliputi kualitas dukungan dan semangat yang diberikan oleh rekan dalam satu tim, kepercayaan terhadap sesema anggota tim, kekompakan, dan keeratan anggota tim.

d. Faktor system, meliputi system kerja, fasilitas kerja yang diberikan oleh pimpinan sekolah, proses organisasi dan kultur kerja dalam organisasi (sekolah).

e. Faktor kontekstual (situasional), meliputi tekanan dan perubahan lingkungan eksternal dan internal. Guru merupakan faktor utama penentu keberhasilan prestasi peserta didik.

Ivor K. Davies (1987:35) mengatakan bahwa seorang mempunyai empat fungsi umum yang merupakan ciri pekerja seorang guru, adalah sebagai berikut: a. Merencanakan yaitu pekerjaan seorang guru menyusun tujuan belajar.

b. Mengorganisasikan Yaitu pekerjaan seorang guru untuk mengatur dan menghubungkan sumber sumber belajar sehingga dapat mewujudkan tujuan belajar dengan cara yang paling efektif, efesien, dan ekonomis mungkin.

c. Memimpin

Yaitu pekerjaan seorang guru untuk memotivasikan, mendorong, dan menstimulasikan murid-muridnya, sehingga mereka siap mewujudkan tujuan belajar.

d. Mengawasi

Yaitu pekerjaan seorang guru untuk menentukan apakah fungsinya dalam mengorganisasikan dan memimpin di atas telah berhasil dalam mewujudkan tujuan yang telah dirumuskan. Jika tujuan belum dapat diwujudkan, maka guru harus menilai dan mengatur kembali situasinya dan bukunya mengubah tujuan.

Pada tingkatan institusional dan instruksional guru berada di lapisan terdepan yang berhadapan langsung dengan peserta didik dan masyarakat. Guru sebagai sebuah profesi yang akan mengantarkan anak-anak penerus bangsa untuk mencapai keberhasilan memiliki peran dan fungsi yang akan semakin kompleks di masa yang akan datang. Oleh karena itu, peningkatan 
kualitas guru membutuhkan penanganan yang lebih serius. Profesi guru menuntut adanya kesadaran dan tanggung jawab yang lebih kuat dalam menjalankan peran dan fungsinya sebagai guru.

\section{METODE PENELITIAN}

Penelitian ini dirancang sebagai penelitian eksplanasi (explanatory research) yaitu menjelaskan hubungan kausal antara variabel-variabel melalui pengujian hipotesis. Apabila ditinjau dari tingkat eksplanasinya termasuk dalam penelitian tingkat eksplanasi asosiatif yaitu untuk menemukan ada tidaknya pengaruh,

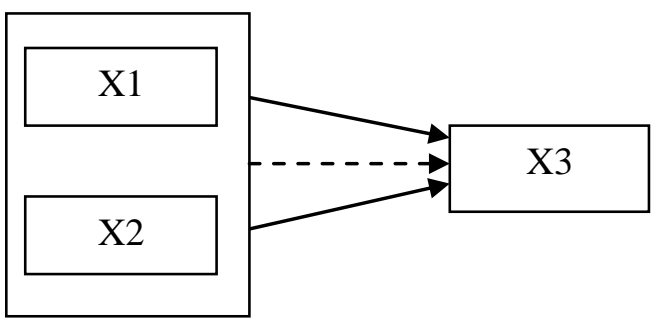

dan apabila ada berapa besar pengaruh variabel bebas terhadap variabel terikatnya. Penelitian ini dilakukan dengan cara menjelaskan gejala-gejala yang timbul oleh suatu objek penelitian, dalam hal ini data diperoleh dari guru ekonomi di SMA sekota Malang.

Variabel bebas dalam penelitian ini adalah profesionalisme guru (X1) dan motivasi kerja (X2) sedangkan variabel terikatnya adalah kinerja guru ekonomi (Y). Berdasarkan tujuan penelitian ini maka peneliti menggunakan pendekatan kuantitatif. Adapun hubungan antar variabel dalam penelitian ini adalah sebagai berikut:

\section{Gambar 1 Hubungan Antar Variabel Penelitian}

Keterangan:

$\mathrm{X} 1=$ Profesionalisme Guru

$\mathrm{X} 2=$ Motivasi Kerja

$\mathrm{Y} \quad=$ Kinerja Guru

$\longrightarrow=$ Pengaruh secara parsial

$-\cdots=$ Pengaruh secara simultan

Populasi dalam penelitian ini adalah seluruh guru ekonomi di SMA sekota Malang yang berjumlah 82 orang. Sampel yang digunakan dalam penelitian ini diambil dari seluruh populasi. Sampel kurang dari 100 orang. Instrumen yang digunakan dalam penelitian ini adalah kuesioner (angket). Skala pengukuran yang digunakan dalam angket di penelitian ini adalah Skala Likert. Instrument yang telah tersebut diambil karena jumlah populasi 
disusun kemudian dilakukan uji coba kepada 32 orang responden.

Metode yang digunakan dalam penelitian ini adalah metode kuantitatif. Data dianalisis dengan analisis statistik deskriptif, analisis statistik inferensial dengan analisis regresi linear berganda, uji asumsi klasik, dan uji hipotesis dengan uji $\mathrm{t}$ dan uji $\mathrm{F}$ dengan bantuan program SPSS (statistical Product and Service Solution) versi 16.00 for windows.

\section{PEMBAHASAN HASIL PENELITIAN}

Hasil dalam penelitian ini menunjukkan bahwa sebagian besar guru ekonomi di SMA sekota Malang memiliki tingkat keprofesionalan yang sangat tinggi, terbukti dengan mayoritas $80,52 \%$ guru memiliki skor sangat tinggi. Sedangkan sebagian kecil responden yakni sekitar 19,48\%, memiliki tingkat keprofesionalan yang tinggi. Sehingga, secara keseluruhan rata-rata tingkat keprofesionalan guru tergolong dalam klasifikasi tinggi. Selain itu, berdasarkan hasil analisis data menunjukkan secara parsial profesionalisme guru berpengaruh positif dan signifikan terhadap kinerja guru ekonomi dengan nilai sig. $\mathrm{t}$ sebesar $(0,000)$ $<\alpha(0,05)$ dan $t_{\text {hitung }}(4,361)>\mathrm{t}_{\text {tabel }}(1,666)$. Temuan hasil penelitian menunjukkan bahwa profesionalisme guru berpengaruh dan signifikan terhadap kinerja guru. Hal ini dapat diartikan bahwa semakin profesional seorang guru dalam melakukan pekerjaannya maka kinerjanya akan semakin meningkat pula.

Hasil dalam penelitian ini menunjukkan bahwa sebagian besar guru ekonomi di SMA sekota Malang memiliki motivasi kerja yang tinggi, terbukti dengan mayoritas $67,53 \%$ guru memiliki skor tinggi dan guru yang memiliki motivasi kerja sangat tinggi mencapai 27,27\%. Namun demikian sebagian kecil guru $5,20 \%$ masih memiliki motivasi kerja yang cukup. Secara keseluruhan rata-rata tingkat motivasi kerja tergolong dalam klasifikasi tinggi. Selain itu, berdasarkan hasil analisis data menunjukkan secara parsial motivasi kerja berpengaruh positif dan signifikan terhadap kinerja guru ekonomi dengan nilai sig. $\mathrm{t}$ sebesar $(0,000)<\alpha(0,05)$ dan $t_{\text {hitung }}$ $(3,650)>\mathrm{t}$ tabel $(1,666)$. Dengan demikian, dapat ditarik kesimpulan bahwa terdapat pengaruh yang positif dan signifikan antara motivasi kerja terhadap kinerja guru ekonomi.

Hasil pengolahan data penelitian dengan menggunakan analisis regresi linear berganda menunjukkan bahwa secara simultan profesionalisme guru dan motivasi kerja berpengaruh positif dan signifikan terhadap kinerja guru ekonomi dengan nilai sig. F sebesar $(0,000)<\alpha(0,05)$. Hasil analisis regresi besar $\mathrm{R}$ Square adalah 0,530. Hal ini berarti $53 \%$ perubahan variabel kinerja guru dipengaruhi oleh 
perubahan variabel profesionalisme guru dan motivasi kerja, sedangkan sisanya sebesar $47 \%$ dipengaruhi oleh faktor lain. Dengan demikian dapat disimpulkan bahwa, makin tinggi profesionalisme guru dan motivasi kerja guru maka makin baik kinerja guru.

Guru yang profesional ditandai dengan adanya penguasaan kemampuan/ kompetensi yang dimiliki guru yang meliputi kompetensi pedagogik, kompetensi kepribadian, kompetensi sosial dan kompetensi profesional. Seorang guru yang dapat menguasai materi serta konsepkonsep mata pelajaran yang diampunya, akan dapat melakukan proses pembelajaran dengan efektif. Menurut Effendi (1997) faktor yang paling dominan berpengaruh terhadap kinerja guru dalam proses belajar mengajar di sekolah adalah pengetahuan guru itu sendiri. Oleh karena itu, guru harus senantiasa berusaha meningkatkan pengetahuannya agar mempunyai wawasan yang luas demi peningkatan kinerjanya.

Motivasi kerja yang dimiliki guru akan mendorong guru untuk bekerja atau mengarahkan aktivitas selama bekerja serta menyebabkan guru mengetahui adanya tujuan yang relevan antara tujuan organisasi dengan tujuan pribadinya. Jika seorang guru mempunyai motivasi kerja yang tinggi, maka guru tersebut akan melakukan pekerjaannya dengan keras, tekun, dan dengan dedikasi tinggi sehingga akan tercapai hasil yang maksimal. Hal ini selaras dengan pendapat Uno (2008:67) yang menyatakan bahwa motivasi erat hubungannya dengan perilaku dan kinerja atau prestasi kerja. Dengan demikian semakin tinggi motivasi seseorang maka semakin tinggi pula kinerjanya begitu pula sebaliknya.

Castetter (dalam Sagala, 2007:4) menegaskan bahwa kualitas proses belajar mengajar sangat dipengaruhi oleh kemampuan profesional guru-gurunya. Seorang guru akan dapat melaksanakan tugasnya dengan apabila memiliki pengetahuan dan keterampilan serta wawasan yang luas dalam bidangnya. Hal ini didasarkan dengan pemikiran bahwa seorang guru akan dapat melaksanakan tugasnya dengan baik apabila memiliki pengetahuan dan keterampilan serta wawasan yang luas dalam bidangnya. Untuk meningkatkan kinerjanya, guru harus selalu berusaha tepat waktu, menggunakan metode dan strategi pembelajaran dengan tepat, serta mengikuti seminar atau pelatihan sehingga dapat meningkatkan kualitas pembelajaran.

Apabila guru memiliki motivasi kerja yang tinggi, maka guru akan memberikan yang terbaik demi kemajuan organisasinya. Motivasi dalam hal ini berfungsi sebagai pendorong usaha dalam pencapaian prestasi. Motivasi kerja guru dapat berasal dari dalam diri guru (motivasi intrinsik) 
maupun dari luar diri guru (motivasi ekstrinsik). Motivasi yang berasal dari dalam diri guru akan menimbulkan kesadaran akan tanggung jawab terhadap pekerjaannya yang lebih baik dibandingkan dengan dorongan yang berasal luar diri guru. Guru yang merasa mampu menerapkan pembelajaran yang disenangi siswa serta memiliki hubungan yang harmonis baik dengan siswa maupun orang tua siswa, akan berdampak pada kinerja guru yang optimal. Seorang guru dapat melaksanakan tugasnya dengan baik apabila memiliki tingkat motivasi dan kemampuan yang mendukung penyelesaian tugasnya tersebut. Motivasi yang dimiliki seseorang untuk melakukan sesuatu tidak akan efektif tanpa didukung oleh pemahaman yang jelas tentang apa yang akan dikerjakan dan bagaimana cara mengerjakannya. Dengan demikian, aspek kemampuan dan motivasi seseorang secara bersama-sama akan berpengaruh terhadap kinerjanya

\section{KESIMPULAN}

Berdasarkan hasil analisis dan pembahasan penelitian yang telah dikemukakan, maka kesimpulan dalam penelitian ini adalah sebagai berikut: a) Profesionalisme guru memiliki pengaruh positif dan signifikan terhadap kinerja guru ekonomi. b) Motivasi kerja memiliki pengaruh positif dan signifikan terhadap kinerja guru ekonomi. c) Profesionalisme guru dan motivasi kerja memiliki pengaruh positif dan signifikan terhadap kinerja guru ekonomi.

Keterbatasan penelitian ini antara lain: a) Penelitian ini mengungkap kinerja guru yang dipengaruhi oleh dua faktor yaitu faktor profesionalisme guru dan faktor motivasi kerja, sedangkan faktor-faktor yang mempengaruhi guru sangat kompleks dan tidak diungkap dalam penelitian ini. b) Pengukuran variabel profesionalisme guru dalam penelitian ini hanya berdasarkan pada persepsi guru-guru ekonomi sehingga hasil yang dicapai tidak diberlakukan secara mutlak.

Saran bagi guru ekonomi yaitu gambaran profesionalisme dan motivasi guru yang berkategori tinggi perlu dipertahankan dan ditingkatkan. Guru diharapkan mampu melakukan perencanaan, pengelolaan pembelajaran serta evaluasi hasil belajar siswa sehingga tujuan yang diharapkan dapat tercapai. Hasil penelitian ini juga diharapkan dapat dijadikan bahan koreksi atau penilaian diri dalam rangka peningkatan kinerja mengajar guru secara berkelanjutan. Bagi sekolah, Koordinasi antara kepala sekolah, para guru dan karyawan perlu ditingkatkan agar tujuan yang diharapkan dapat dicapai dengan baik. Pihak sekolah diharapkan dapat mendukung program-program pemerintah dalam rangka peningkatan profesionalisme guru demi tercapainya 
pembelajaran yang berkualitas. Bagi Dinas

Pendidikan, Dalam upaya mempertahankan serta meningkatkan kinerja guru, Dinas Pendidikan hendaknya senantiasa melakukan perencanaan strategik dalam pengembangan dan peningkatan profesionalisme guru secara berkesinambungan dengan cara mengadakan pelatihan-pelatihan dan pendidikan bagi guru ekonomi. sedangkan bagi peneliti selanjutnya, Dapat menjadikan penelitian ini sebagai referensi dalam memecahkan permasalahan yang terkait dengan kinerja guru. Apabila peneliti selanjutnya melakukan penelitian yang sejenis dengan penelitian ini, disarankan untuk mengukur variabel profesionalisme guru dengan menggunakan data uji kompetensi guru (UKG) yang diperoleh dari masing-masing sekolah yang diteliti.

\section{DAFTAR PUSTAKA}

Departemen Pendidikan Nasional. 2003. Kegiatan Belajar Mengajar yang Efektif. Jakarta: Depdiknas.

Davies, Ivor K. 1987. Pengelolaan Belajar. Jakarta: PT. Rajawali Pers Effendi. H.A.R. 1997. Manajemen Pendidikan. Jakarta: Depdikbud.

Fattah, Nanang. 2003. Landasan Kependidikan. Bandung: PT Remaja Rodaskarya.
Hamalik.Oemar. 2003. Perencanaan Pengajaran Berdasarkan Pendekatan sistem. Yogyakarta: Andi Offset.

Hasibuan, Malayu SP. 2003. Organisasi Dan Motivasi. Jakarta: PT Bumi Aksara.

Komarudin. 2000. Kamus Istilah Karya Tulis Ilmiah. Jakarta: Bumi Aksara.

Luthans, Fred. 2008. Organizational Behaviour. New York: McGraw-Hill Inc, $\mathrm{p}$.

Mulyasa, E. 2008. Standar Kompetensi dan Sertifikasi Guru. Bandung: Remaja RosdaKarya.

Peraturan Pemerintah RI No. 19 Tahun 2005 Tentang Standar Nasional Pendidikan. 2005. Jakarta: CV. Eko Jaya.

Robbins, S. P. \& Judge, T. A. 2007. Perilaku Organisasi. Alih Bahasa oleh Diana Angelina. Jakarta: Salemba Empat.

Roth, G., Assor, A., Kanat-Maymon, Y, \& Kaplan, H. 2007. Autonomous Motivation for Teaching: How SelfDitermined Teaching May Lead to SelfDetermined Learning Journal of Education Psychology. 99 (4): 761774.Sagala, Saiful. 2006. Kemampuan Profesional Guru dan Tenaga Kependidikan. Bandung: Alfabeta Sagala, Saiful. 2006. Kemampuan Profesional Guru dan Tenaga Kependidikan. Bandung: Alfabeta 
ISSN: 2442-9449 Vol.3.No.1 (2015) 24-35

Santoso, Kurniawan Adi. 02 September 2013. Guru, Jagalah Profesionlismemu. Malang Post, hlm 1.

Tilaar, H. A. R. 2002. Membenahi Pendidikan Nasional. Jakarta: PT. Rineka Cipta. 2005. Undang-undang Nomor 14 Tahun 2005 tentang Guru dan Dosen.

Usman, M. Uzer. 2010. Menjadi Guru Profesional. Bandung: PT. Remaja Rosda Karya.

Yamin, M. 2007. Profesionalisme Guru \& Implementasi KTSP. Jakarta: Gaung Persada Press 